\title{
Influence of starches from different sources on protein utilization in rats
}

\author{
BY C. NAGESWARA RAO AND B. S. NARASINGA RAO \\ National Institute of Nutrition, Indian Council of \\ Medical Research, Hyderabad - 500007 , India
}

(Received 6 January 1977 - Accepted 7 October 1977)

\begin{abstract}
I. The role of the starch component of cereals and legumes on the utilization of casein-protein was studied. 2. In comparison with maize starch the legume and potato starches caused a significant lowering of net protein utilization (NPU). And this reduction in NPU could be partially restored by cooking the diets before they were fed to the rats.

3. It is suggested that in NPU studies involving rats the experimental diet should always be cooked so that the conclusions drawn may be applicable to human diets.
\end{abstract}

The amount of dietary protein necessary to meet the protein requirement largely depends on the quality of protein. Among the factors which influence the utilization of dietary protein is thought to be the source of carbohydrate. Net protein utilization (NPU) (Miller \& Bender, 1955) of proteins of plant origin do not always correlate well with the chemical score (Block \& Mitchell, 1946). One of the explanations for this may be that some of the non-protein components, such as carbohydrate, of the food may influence protein utilization. Earlier work from this Institute revealed that there are marked differences in in vitro digestibility of starches from different pulses (Srinivasa Rao, 1969). There is also some information in the literature indicating that protein utilization may be affected by the nature of starch (Chang, Soong \& Miller, 1967; Marshall, Womack, Hildebrand \& Munson, 1969; Buraczewski, Porter, Rolls \& Zebrowska, 197I; El-Harith, Dickerson \& Walker, 1976). Since in developing countries most of the dietary protein is derived from cereals, tubers and pulses, which are also the main source of carbohydrate (starch) in the diet it was considered important to determine the extent to which starch from different dietary sources influences dietary protein utilization.

In this investigation, the effect of starches from cereals, legumes and tubers on the utilization of a standard protein, casein, was studied in rats.

\section{MATERIALS AND METHODS}

Animals. Weanling albino rats of the Wistar strain, from the inbred colony of the National Institute of Nutrition, Hyderabad, were used for the study. Each group contained six animals, three males and three females.

Starches. The study was conducted in three separate experiments. In the first experiment the starches studied were maize (Zea mays), wheat (Triticum aestivum), jowar (Sorghum vulgare), tapioca (Manihot єsculenta), red gram (Cajanus cajan), black gram (Phaseolus mungo) and green gram (Phaseolus aureus Roxb). In the second experiment, maize, cooked and uncooked red gram, rice (Oryza sativa), ragi (Eleusine coracana), Bengal gram (Cicer aerietinum), potato (Solanum tuberosum), potato amylose and a mixture of equal amounts of red gram and maize were studied. In the third experiment, cooked and uncooked starches of maize, red gram, green gram and potato were included. Maize starch served as a control in each of the experiments. The starches from the different sources were isolated by the 
Table I. Results of analysis of starches derived from legumes, cereals and tubers

\begin{tabular}{|c|c|c|c|}
\hline Source of starch & $\begin{array}{l}\text { Moisture } \\
(\mathrm{g} / \mathrm{kg})\end{array}$ & $\begin{array}{l}\text { Total glucose } \\
(\mathrm{g} / \mathrm{kg})\end{array}$ & $\begin{array}{l}\text { Nitrogen } \\
(\mathrm{g} / \mathrm{kg})\end{array}$ \\
\hline \multicolumn{4}{|l|}{$\begin{array}{l}\text { Maize (Zea mays): } \\
\text { Sample no.: }\end{array}$} \\
\hline 1 & 100 & 1096 & $1 \cdot 3$ \\
\hline 2 & 101 & 1123 & $1 \cdot 3$ \\
\hline 3 & 99 & 1104 & $1 \cdot 3$ \\
\hline Wheat (Triticum destivum) & 97 & 1098 & $1 \cdot 4$ \\
\hline Jowar (Sorghum vulgare) & 99 & 1087 & 0.7 \\
\hline Rice (Oryza sativa) & IOI & II 20 & I.2 \\
\hline Ragi (Eleusine coracana) & 103 & 1106 & $1 \cdot 3$ \\
\hline \multicolumn{4}{|l|}{$\begin{array}{l}\text { Red gram (Cajanus cajan): } \\
\text { Sample no.: }\end{array}$} \\
\hline 1 & 101 & 1144 & $1 \cdot 2$ \\
\hline 2 & 102 & II 37 & $1 \cdot 3$ \\
\hline 3 & 106 & I 128 & I'I \\
\hline \multicolumn{4}{|c|}{$\begin{array}{l}\text { Green gram (Phaseolus aureus Roxb): } \\
\text { Sample no.: }\end{array}$} \\
\hline I & 98 & II 104 & I.3 \\
\hline 2 & 104 & II 3i & $1 \cdot 2$ \\
\hline Bengal gram (Cicer aerietinum) & 98 & 1147 & $1 \cdot 2$ \\
\hline Black gram (Phaseolus mungo) & 100 & 1090 & $I \cdot I$ \\
\hline Tapioca (Manihot esculenta) & 102 & 1108 & 0.8 \\
\hline \multicolumn{4}{|l|}{ Potato (Solanum tuberosum): } \\
\hline \multicolumn{4}{|l|}{ Sample no.: } \\
\hline I & 100 & II 123 & 0.6 \\
\hline 2 & 97 & 1141 & 0.5 \\
\hline
\end{tabular}

tabling process (Watson, Williams \& Wakely, I95I). Alkali-washing with sodium hydroxide solution $(4 \mathrm{~g} / 1)$ was employed to remove the last traces of protein. In this way, pure starches containing less than $\mathrm{r} .6 \mathrm{~g}$ nitrogen $/ \mathrm{kg}$ were obtained and used in the study.

Analytical methods. N content of the diets and faecal $\mathrm{N}$ were estimated using the conventional macro-Kjeldahl procedure and carcass $\mathrm{N}$ was estimated by the method of Hegsted \& Chang (1965). For the estimation of NPU, the method of Miller (1963) was adopted. Purity of starch was determined by estimating the glucose content of various sources of starch after acid-hydrolysis, by the glucose-oxidase method of Meites (1965). The results of analysis of starch are given in Table I. The various starches were tested for the presence of sugars other than glucose using descending paper chromatography as described by Smith ( 1960$)$ using a propan-2-ol-water $(80: 20, \mathrm{v} / \mathrm{v})$ developing solvent system. Amylose content of the starches was estimated by the method of Williams, Kuzina \& Hlynka (1970).

Experimental design. Rats weaned at $2 \mathrm{I} \mathrm{d}$ of age were individually caged and fed on the stock diet providing $200 \mathrm{~g}$ protein $/ \mathrm{kg}$ for $7 \mathrm{~d}$. At the end of this period the animals were allocated randomly to the treatment groups. Each experimental group constituted three male and three female rats and the animals were caged and fed individually. Each of the starches was incorporated at $780 \mathrm{~g} / \mathrm{kg}$ diet. Other components of the diets were $(\mathrm{g} / \mathrm{kg})$ : I20 casein ( $100 \mathrm{~g}$ protein $/ \mathrm{kg}$ ), 50 refined peanut oil, 40 mineral mixture (Association of Official Agricultural Chemists, I965), Io vitamin mixture ((US) National Research Council, 1963), I choline chloride. The animals were given food and water ad lib. throughout the experimental period of $10 \mathrm{~d}$. For the purpose of estimating NPU (Miller, I963) a group of rats was given a protein-free diet in which casein in the maize-starch diet was replaced by 
Table 2. Effect of different starches derived from legumes, cereals and tubers on gain in weight and food conversion efficiency in rats $\dagger$

(Mean values with their standard errors; no. of animals in parentheses)

\begin{tabular}{|c|c|c|c|c|c|c|}
\hline \multirow{2}{*}{ Source of starch } & \multicolumn{2}{|c|}{$\begin{array}{l}\text { Food intake } \\
\qquad(\mathrm{g} / \mathrm{d})\end{array}$} & \multicolumn{2}{|c|}{$\begin{array}{l}\text { Gain in wt } \\
(\mathrm{g} / \mathrm{d})\end{array}$} & \multicolumn{2}{|c|}{$\begin{array}{l}\text { Food conversion } \\
\text { efficiency } \ddagger\end{array}$} \\
\hline & Mean & $\mathrm{SE}$ & Mean & $\mathbf{S E}$ & Mean & SE \\
\hline \multicolumn{7}{|l|}{ Cereals: } \\
\hline Maize (Zea mays) (18) & $8 \cdot 4$ & 0.15 & $2 \cdot 7$ & 0.09 & 0.32 & 0.009 \\
\hline $\begin{array}{l}\text { Wheat (Triticum } \\
\text { aestivum) }(6)\end{array}$ & $8 \cdot 4$ & 0.22 & $2 \cdot 8$ & 0.14 & 0.33 & 0.012 \\
\hline $\begin{array}{l}\text { Jowar (Sorghum } \\
\text { vulgare) (6) }\end{array}$ & $7 \cdot 5$ & $0.27^{*}$ & $2 \cdot I$ & 0.16 & 0.28 & 0.017 \\
\hline Rice (Oryza sativa) (6) & $8 \cdot 6$ & 0.19 & $2 \cdot 7$ & $0 \cdot 14$ & 0.31 & 0.021 \\
\hline $\begin{array}{l}\text { Ragi (Eleusine } \\
\text { coracana) }(6)\end{array}$ & $8 \cdot 7$ & 0.40 & $2 \cdot 6$ & 0.48 & 0.28 & 0.049 \\
\hline \multicolumn{7}{|l|}{ Legumes: } \\
\hline $\begin{array}{l}\text { Red gram (Cajanus } \\
\text { cajan) (I } 8)\end{array}$ & $7 \cdot 0$ & $0.22^{* * *}$ & 0.6 & $0.18^{* * *}$ & 0.07 & $0.027^{* * *}$ \\
\hline $\begin{array}{l}\text { Black gram (Phaseolus } \\
\text { mungo) (6) }\end{array}$ & $6 \cdot 9$ & $0.17^{* * *}$ & $\mathbf{I} \cdot \mathbf{I}$ & $0.24^{* * *}$ & 0.16 & $0.032^{* * *}$ \\
\hline $\begin{array}{l}\text { Green gram (Phaseolus } \\
\text { aureus Roxb) (12) }\end{array}$ & $7 \cdot 9$ & 0.25 & $1 \cdot 7$ & $0.17^{* * *}$ & 0.21 & $0.015^{* * *}$ \\
\hline $\begin{array}{l}\text { Bengal gram (Cicer } \\
\text { aerietinum) }(6)\end{array}$ & $8 \cdot 2$ & 0.34 & $2 \cdot 3$ & 0.32 & 0.27 & 0.032 \\
\hline Roots and tubers: & & & & & & \\
\hline $\begin{array}{l}\text { Tapioca (Manihot } \\
\text { esculenta) }(6)\end{array}$ & $8 \cdot 2$ & 0.22 & 2.5 & 0.12 & $0.3 \mathrm{I}$ & 0.011 \\
\hline $\begin{array}{c}\text { Potato (Solanum } \\
\text { tuberosum) ( } 2)\end{array}$ & $9 \cdot 9$ & $0.18 * * *$ & $1 \cdot 3$ & $0.18^{* * *}$ & 0.13 & $0.019^{* * *}$ \\
\hline Amylose powder (6) & $9 \cdot 8$ & $0.24^{* * *}$ & $1 \cdot 4$ & $0.28 * * *$ & 0.14 & $0.028 * * *$ \\
\hline Mixed starch§ (6) & $8 \cdot 9$ & 0.37 & $2 \cdot 6$ & 0.31 & 0.54 & 0.042 \\
\hline
\end{tabular}

maize starch. The number of animals in this group was fixed by the statistical formula $N \times \sqrt{ } n$ of Gridgeman (1963), where $N$ is the number of animals in each experimental group and $n$ is the number of experimental groups. Since there were seven, nine and eight treatment groups in the three experiments respectively the corresponding number of animals in the protein-free diet groups were sixteen, eighteen and seventeen respectively. Weight gain and food intake of the animals were recorded. Faeces were collected daily from individual animals during the last $3 \mathrm{~d}$ of the feeding period. True digestibility was determined by using values for metabolic faecal $\mathrm{N}$ obtained in animals given the protein-free diet.

\section{RESULTS}

The control groups given maize-starch diets in the three separate experiments showed similar values. The three sets of results, which were obtained at three different times were therefore pooled and analysed by the analysis of variance (Fisher, 1958).

Food intake. The diets containing starch derived from red gram and black gram were consumed in much smaller quantities $(P<0.001)$ than were diets containing other sources of starch. 
Table 3. Digestibility and net protein utilization (NPU) of casein-protein with different sources of starch in the diet of rats $\dagger$

(Mean values with their standard errors; values in parentheses indicate the total no. of animals in the three experiments)

\begin{tabular}{|c|c|c|c|c|c|c|}
\hline \multirow[b]{2}{*}{ Source of starch } & \multicolumn{2}{|c|}{$\begin{array}{l}\text { Digestibility of } \\
\text { dry matter }\end{array}$} & \multicolumn{2}{|c|}{$\begin{array}{l}\text { True digestibility } \\
\text { coefficient }\end{array}$} & \multicolumn{2}{|c|}{ NPU } \\
\hline & Mean & SE & Mean & SE & Mean & $\mathbf{S E}$ \\
\hline \multicolumn{7}{|l|}{ Cereals: } \\
\hline Maize (Zea mays) (I 8) & 0.96 & 0.002 & 0.93 & 0.005 & 0.67 & 0.021 \\
\hline $\begin{array}{l}\text { Wheat (Triticum } \\
\text { aestivum) }(6)\end{array}$ & 0.95 & 0.003 & 0.93 & 0.005 & 0.74 & 0.028 \\
\hline Jowar (Sorghum vulgare) (6) & 0.95 & 0.006 & 0.95 & 0.013 & 0.73 & 0.021 \\
\hline Rice (Oryza sativa) (6) & 0.96 & 0.004 & 0.97 & 0.008 & 0.65 & $0.02 \mathrm{I}$ \\
\hline Ragi (Eleusine coracana) (6) & 0.97 & 0.006 & 0.97 & 0.009 & 0.58 & 0.058 \\
\hline \multicolumn{7}{|l|}{ Legumes: } \\
\hline $\begin{array}{l}\text { Red gram (Cajanus } \\
\text { cajan) (I 8) }\end{array}$ & 0.88 & $0.009^{* * *}$ & 0.79 & $0.0 I^{* * *}$ & 0.55 & $0.026^{* * *}$ \\
\hline $\begin{array}{l}\text { Black gram (Phaseolus } \\
\text { mungo) }(6)\end{array}$ & 0.93 & $0.003^{*}$ & 0.88 & 0.018 & 0.55 & $0.023^{* *}$ \\
\hline $\begin{array}{l}\text { Green gram (Phaseolus } \\
\text { aureus Roxb) (12) }\end{array}$ & 0.95 & 0.004 & 0.93 & 0.007 & $0.6 \mathrm{I}$ & 0.020 \\
\hline $\begin{array}{l}\text { Bengal gram (Cicer } \\
\text { aerietinum) (6) }\end{array}$ & 0.95 & 0.009 & 0.89 & 0.023 & 0.70 & 0.067 \\
\hline \multicolumn{7}{|l|}{ Roots and tubers: } \\
\hline $\begin{array}{l}\text { Tapioca (Manihot } \\
\text { esculenta) (6) }\end{array}$ & 0.96 & 0.003 & 0.92 & 0.009 & 0.76 & $0.050^{*}$ \\
\hline $\begin{array}{l}\text { Potato (Solanum } \\
\text { tuberosum) (I 2) }\end{array}$ & 0.66 & $0.028^{* * *}$ & 0.83 & $0.016^{* * *}$ & 0.45 & $0.036 * * *$ \\
\hline Amylose powder (6) & 0.72 & $0.01 I^{* * *}$ & 0.78 & $0.012^{* * *}$ & 0.42 & $0.047^{* * *}$ \\
\hline Mixed starch (6) & 0.96 & 0.005 & $0.9 \mathrm{I}$ & 0.010 & 0.67 & 0.049 \\
\hline
\end{tabular}

The effect of the starch was statistically significant: ${ }^{*} P<0.05,{ }^{*} P<0.0 \mathrm{I},{ }^{* *} P<0.00 \mathrm{I}$.

$\uparrow$ All comparisons were made with maize starch as the standard.

Gain in weight. The gain in body-weights of animals fed on diets with pulse or potato starches was significantly $(P<0.00 \mathrm{I})$ lower as compared to the body-weight gain with the cereal-starch diets. However, with diets containing a mixture of equal amounts of red gram and maize starches, the gain in weight was comparable to that seen with diets containing only cereal starch (Table 2).

Food conversion efficiency. The food conversion efficiency (increment in body-weight/g food intake) of diets containing legume or potato starches was much lower compared to those containing cereal starches $(P<0.001)$ (Table 2$)$.

True digestibility. The true digestibility of casein-protein appeared to be lower when the source of starch in the diet was either red gram or potato as compared to that of diets with cereal starches $(P<0.00 \mathrm{I})$ (Table 3$)$.

NPU. The NPU of casein was significantly lower $(P<0.001)$ when the dietary source of starch was either red gram, black gram or potato than when the source of starch was any of the cereals (Table 3 ).

Effect of cooking. The effect of cooking on the diet, expressed as NPU of casein fed with different starches, is shown in Table 4. The analysis of variance (Table 4) of the results showed that NPU, gain in body-weight and food intake all improved on cooking in the instance of legume and potato starches. The significant interaction in gain in weight and NPU suggested that the improvement observed was of different magnitude for different 
Table 4. Effect of cooking on net protein utilization (NPU) of casein-protein with different sources of starch in the diet of rats $\dagger$

(Mean values for no. of animals given in parentheses)

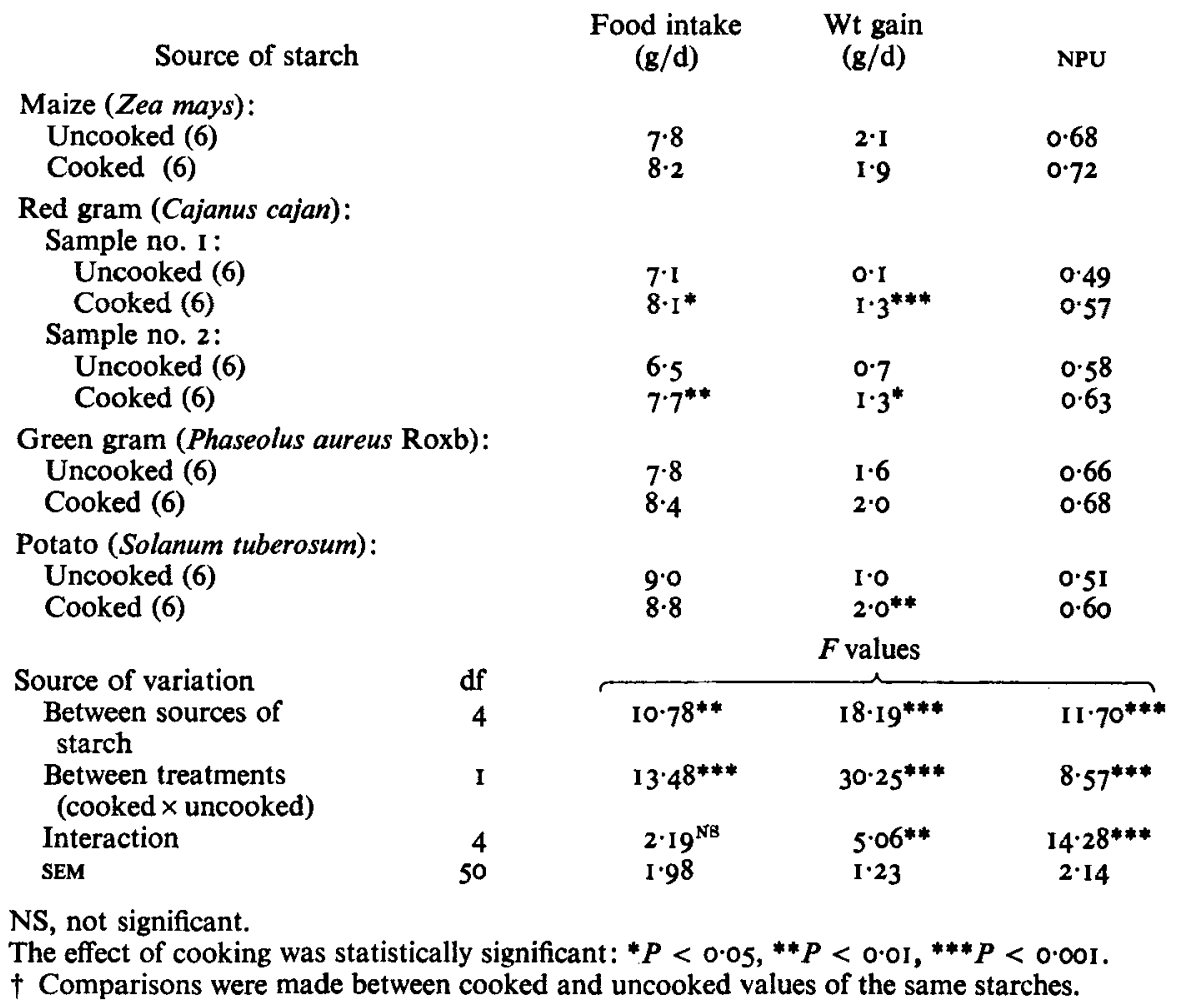

starches. Such interaction was not observed for food intake. The faecal weights in the instance of animals on the potato-starch diet significantly $(P<0.001)$ decreased when the cooked diet was fed.

Composition of different starches. When the starches were analysed for mono- and oligosaccharides by paper chromatography only a single compound corresponding to D-glucose was observed. Glucose estimated in the starches accounted for almost all the starch. The amylose content of the legume and potato starches was higher than that of the cereal starches (Table 5).

\section{DISCUSSION}

Analysis of variance (Table 6) of the results obtained in the present study indicated that there were significant differences between groups, in growth, food conversion efficiency, NPU and digestibility of casein. Protein utilization was generally poor when the diets contained legume or potato starch as compared with those containing cereal starches. Among the legumes however, starch from Bengal gram was better than starches from other legumes, and it was comparable to cereal starches. Among the tubers, potato starch was inferior to cereal starches while tapioca starch was as good as cereal starches.

Differences with regard to protein utilization in diets containing different carbohydrates have been reported by other workers, the results of which are in support of the present 
Table 5. Relationship between amylose contents of different sources of starch $(\mathrm{g} / \mathrm{kg})$ and nct protcin utilization (NPU) of casein-protein in diets containing these starches

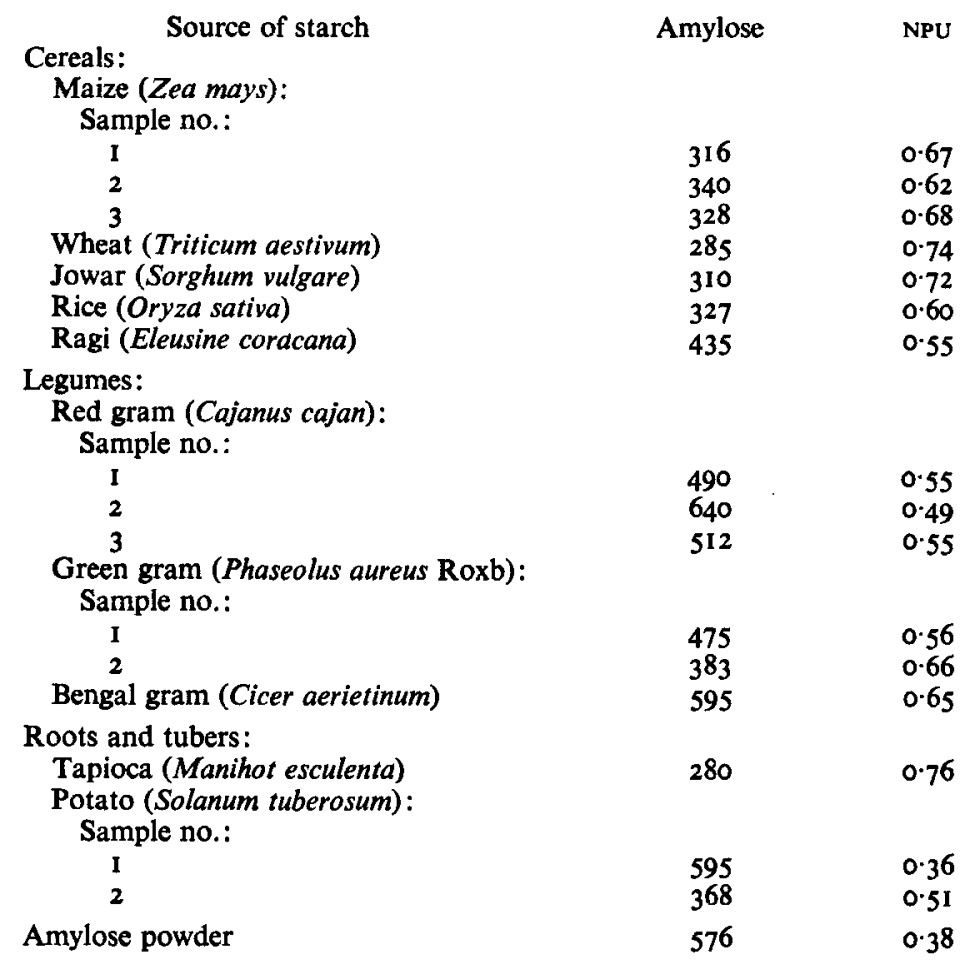

Measurement ... Source of variation

Between sources of starch

Error
Table 6. Analysis of variance of results obtained for different sources of starch in diets for rats

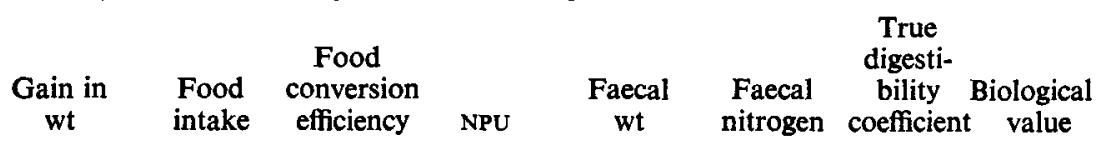

NPU, net protein utilization.

findings. Harper \& Katayama (1953) reported that growth of rats on a diet containing $90 \mathrm{~g}$ casein $/ \mathrm{kg}$ was better when the diet contained maize starch than when it contained sucrose. El-Harith et al. (1976) have recently reported that food conversion efficiency and NPU of a casein-containing diet was poorer with potato starch than with cereal or cassava (Manihot esculenta) starch.

There may be several explanations for the impaired utilization of protein in the presence of some starches. The starches may interfere with the digestibility of proteins. Low values for NPU of casein in diets containing legume and potato starch were accompanied by increased excretion of $\mathbf{N}$ in faeces. Several workers have reported low digestibility of 
casein in diets containing raw potato starch (Booher, Behan \& McMeans, I95I; Harper, Katayama \& Jelinek, 1952). In the present study low digestibility of protein was also accompanied by low biological value indicating that the amino acid utilization in the body was also impaired when these starches were given.

Utilization of casein in diets containing different starches appears to be related to the digestibility of starches themselves (Booher et al. 195I; El-Harith et al. 1976). With diets containing starches which impaired protein utilization, bulky faeces were excreted by rats, indicating impaired digestibility of starch. Digestibility of starch itself is known to be directly related to the amylose content of the starch. In the present study a highly significant correlation $(r-0.8)$ between the amylose content of the starch and the NPU of casein in diets containing these starches was observed. The starches investigated in this study contained no abnormal carbohydrates or oligosaccharides which may be poorly digested and thus impair protein utilization. It is likely that apart from interfering with protein digestibility, the poorly-digested starches of legumes and potato can interfere with amino acid utilization due to a time lag between amino acid absorption and sugar absorption (Geiger, Bancroft \& Hagerty, 1950; Bancroft, Geiger \& Hagerty, I951; Thomson \& Munro, 1955; Marfatia \& Srinivasan, 1960).

In the present investigation, poor utilization of protein was observed when certain of the starches were given in the raw state. In practice, however, these foods are invariably cooked before they are eaten. When the legume starches and potato starch were cooked before feeding, the protein utilization considerably improved. Improvement in protein utilization on cooking diets containing potato starch has been reported by other investigators (Jelinek, Katayama \& Harper, 1952; Wittemore, Taylor \& Elsley, 1973). In practical human nutrition, these starches may not have any deleterious effect on protein utilization since these are cooked before they are consumed. Legumes are generally consumed in combination with cereals. It was also observed that a combination of pulse and cereal starches in proportions comparable to those that are normally consumed by man did not have any deleterious effect on the utilization of casein. Although the observations made with raw starches in the present study may not be entirely relevant to human nutrition, they may be of practical importance in the determination of the NPU of the proteins of diets in which cereals and pulses contribute a large proportion of the protein as well as of the carbohydrate, for in such diets much of the carbohydrate is present as starch. In the determination of NPU with rats the diets often include uncooked foods which, if they contain certain starches, may cause the result to be lower than expected. The present results indicate that in evaluating NPU of human diets containing cereals and legumes, the diets should be cooked before use.

The authors are grateful to Dr S. G. Srikantia, Director, National Institute of Nutrition, Hyderabad for his valuable advice and encouragement, Mr A. Nadamuni Naidu for his help in statistical analysis of the results and $\mathrm{Mr} \mathrm{D}$. Laxminarayana for technical assistance.

\section{REFERENCES}

Association of Official Agricultural Chemists (1965). Official Methods of Analysis, 10th ed., p. 779. Washington, DC: Association of Official Agricultural Chemists.

Bancroft, R. W., Geiger, E. \& Hagerty, E. B. (195I). Endocrinology 49, 149.

Block, R. J. \& Mitchell, H. H. (1946). Nutr. Abst. Rev. r6, 249.

Booher, L. E., Behan, I. \& McMeans, E. (I95I). J. Nutr. 45, 75.

Buraczewski, S., Porter, J. W. G., Rolls, B. A. \& Zebrowska, T. (1971). Br. J. Nutr. 25, 299.

Chang, Y. O., Soong, C. C. \& Miller, G. J. (1967). J. Fd Sci. 32, I35.

El-Harith, A. E., Dickerson, J. W. T. \& Walker, R. (1976). J. Sci. Fd Agric. 27, 52 I.

Fisher, R. A. (1958). Statistical Methods for Research Workers. Edinburgh: Oliver and Boyd.

Geiger, E., Bancroft, R. W., \& Hagerty, E. B. (1950). J. Nutr. 42, 577. 
Gridgeman, N. T. (1963). Statistical Considerations on the Size of Control Groups in Evaluation of Protein Quality, Publ. no. I IO0, p. 36. Washington, DC: National Academy of Sciences - National Research Council.

Harper, A. E. \& Katayama, M. C. (1953). J. Nutr. 49, 26 I.

Harper, A. E., Katayama, M. C. \& Jelinek, B. (1952). Can. J. med. Sci. 30, 578.

Hegsted, D. M. \& Chang, Y. O. (I965). J. Nutr. 85, 159.

Jelinek, B., Katayama, M. C. \& Harper, A. E. (1952). Can. J. med. Sci. 30, 447.

Marfatia, U. \& Srinivasan, A. (1960). J. Nutr. 70, 156.

Marshall, M. W., Womack, M., Hildebrand, H. E. \& Munson, A. W. (1969). Proc. Soc. exp. Biol. Med. r32, 227.

Meites, S. (editor) (1965). In Standard Methods of Clinical Chemistry, vol. 5, p. I I 3. New York and London: Academic Press.

Miller, D. S. (1963). Evaluation of Protein Quality, Publ. no. 1100 , p. 34. Washington, DC: National Academy of Sciences - National Research Council.

Miller, D. S. \& Bender, A. E. (1955). Br. J. Nutr. 9, 382.

National Research Council (1963). Evaluation of Protein Quality, Publ. no. I I00, p. 31. Washington, DC: National Academy of Sciences - National Research Council.

Smith, I. (editor) (1960). In Chromatographic and Electrophoretic Techniques, vol. I, p. 246. London: William Heinemann.

Srinivasa Rao, P. (1969). Indian J. med. Res. 57, 2151 .

Thomson, W. S. T. \& Munro, H. N. (1955). J. Nutr. 56, 139.

Watson, S. A., Williams, C. B. \& Wakely, R. D. (195I). Cereal Chem. 28, 105.

Williams, P. C., Kuzina, F. D. \& Hlynka, I. (1970). Cereal Chem. 48, 4 II.

Wittemore, C. T., Taylor, A. G. \& Elsley, F. W. H. (1973). J. Sci. Fd Agric. 24, 539. 